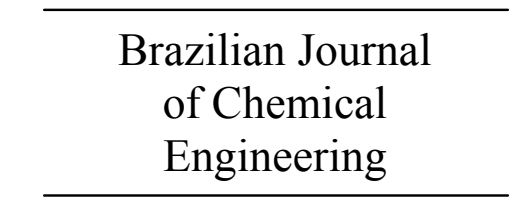

ISSN 0104-6632

Printed in Brazil

www.abeq.org.br/bjche

Vol. 30, No. 03, pp. 499 - 506, July - September, 2013

\title{
INFLUENCE OF CO-SUBSTRATES IN THE ANAEROBIC DEGRADATION OF AN ANIONIC SURFACTANT
}

\author{
D. Y. Okada ${ }^{1 *}$, A. S. Esteves ${ }^{1}$, T. P. Delforno ${ }^{1}$, J. S. Hirasawa ${ }^{1}$, \\ I. C. S. Duarte ${ }^{2}$ and M. B. A. Varesche ${ }^{1}$ \\ ${ }^{1}$ Department of Hydraulics and Sanitation, School of Engineering of São Carlos, University of São Paulo, \\ Phone: + (55) (16) 3373 8358, Fax: + (55) (16) 3373 9550, Trabalhador São-Carlense Avenue, No. 400, \\ Zip Code 13566-590, São Carlos - SP, Brazil. \\ *E-mail: dagokada@gmail.com; varesche@sc.usp.br \\ ${ }^{2}$ Federal University of São Carlos, Campus Sorocaba, João Leme dos Santos Highway (SP 264), \\ Km 110, Zip Code 18052-780, Sorocaba - SP, Brazil. \\ E-mail: iolanda@ufscar.br
}

(Submitted: January 23, 2012 ; Revised: July 14, 2012 ; Accepted: July 24, 2012)

\begin{abstract}
The removal of linear alkylbenzene sulfonate (LAS) was evaluated in a UASB reactor using shortchain alcohols (ethanol and methanol) and complex co-substrate (yeast extract). Using only methanol and ethanol as co-substrates resulted in removal of LAS between 30 and $41 \%$. At the end, addition of a complex substrate (yeast extract) increased the removal of LAS to 50\%. During the assay, water supply aeration increased the volatile fatty acid of the effluent $\left(70 \mathrm{mg} \mathrm{HAc} . \mathrm{L}^{-1}\right)$ and decreased the removal of LAS (from 40 to $30 \%$ ). According to the fluorescence in situ hybridization (FISH) results, the amount of Archaea decreased due to water supply aeration (from 64 to 48\%). Furthermore, addition of complex co-substrate increased the total anaerobic bacteria and methanogenic archaea content (three and four log units, respectively), which were estimated using the most probable number technique.

Keywords: Linear alkylbenzene sulfonate; Acetic acid; Methanogenic archaea; UASB; FISH.
\end{abstract}

\section{INTRODUCTION}

Linear alkylbenzene sulfonate (LAS) is a surfactant that contains a sulfonated aromatic ring attached to a linear alkyl chain with 10 to 14 carbon atoms. In wastewater treatment plants (WWTP), the LAS concentration varies from 1 to $18 \mathrm{mg} . \mathrm{L}^{-1}$ (Morita and Santana, 2005; Mungray and Kumar, 2009).

Only primary biodegradation was found under anaerobic conditions; complete degradation was still not observed (Angelidaki et al., 2004). Many studies have assessed LAS degradation using anaerobic reactors, such as upflow anaerobic sludge blankets (UASB) (Almendariz et al., 2001; Sanz et al., 2003; Lobner et al., 2005), horizontal-flow immobilized biomasses (Duarte et al., 2008; Oliveira et al., 2009), stirred sequencing batches (Duarte et al., 2010) and fluidized beds (Oliveira et al., 2010). Among these methods, UASB reactors have been widely assessed and are commonly used in WWTP.

In UASB reactors, degradation of LAS varied from 13 to $85 \%$ with the highest efficiency due to withdrawal of co-substrates, at an influent concentration of $5 \mathrm{mg} . \mathrm{L}^{-1}$ (Sanz et al., 2003). Despite the greater efficiency, a loss of biomass $(11.5 \%)$ was reported in this condition (Sanz et al., 2003) and the requirement of other nitrogen and carbon sources for degradation of LAS was reported in facultative anaerobic conditions (Khleifat, 2006; Abboud et al., 2007). Some complex co-substrates were used in

*To whom correspondence should be addressed 
studies with LAS, such as glucose, maltose, or sucrose (Sanz et al., 2003; Abboud et al., 2007), but none used only short-chain alcohol (e.g., ethanol, methanol) which could reduce costs. Furthermore, short-chain alcohols can be used to reactivate bacteria with the ability to degrade LAS (Schörberl, 1989).

In the present study, LAS removal was evaluated in a UASB reactor fed with short-chain alcohols (ethanol and methanol). In addition, yeast extract was added to the reactor to compare the LAS removal using a complex co-substrate.

\section{MATERIAL AND METHODS}

\section{LAS}

The linear alkylbenzene sulfonate used in the present study was a commercial mixture of $\mathrm{C}_{10}-\mathrm{C}_{13}$ homologues and was provided by Aldrich (CAS no. 25155-30-0, technical grade).

\section{Inoculum}

The inoculum consisted of granular sludge from a UASB reactor used to treat effluent from a poultry slaughterhouse (Dacar Poultry, Tietê-SP, Brazil).

\section{Adsorption Experiment}

Adsorption assays were conducted to evaluate the adsorption of LAS onto inoculum. Batches were carried out using $250 \mathrm{~mL}$ of mineral medium (the concentration of $\mathrm{MgCl}_{2} \cdot 6 \mathrm{H}_{2} \mathrm{O}$ was adjusted to $25 \mathrm{mg} . \mathrm{L}^{-1}$ ) (Angelidaki et al., 1990), LAS and inoculum. The initial LAS concentration varied from 5 to $45 \mathrm{mg} . \mathrm{L}^{-1}$. The inoculum was sterilized (Mogensen et al., 2003) and was used at a total solid (TS) concentration of $6 \mathrm{~g}$ TS.L $\mathrm{L}^{-1}$.

\section{UASB Reactor}

The UASB reactor was operated with a hydraulic retention time (HRT) of $24 \mathrm{~h}$ (flow $0.44 \mathrm{~L} . \mathrm{d}^{-1}$ ) under mesophilic conditions $\left(30 \pm 1{ }^{\circ} \mathrm{C}\right)$. The reactor consisted of acrylic and steel and possessed a volume of $10.5 \mathrm{~L}$.

The feed consisted of mineral medium (the concentration of $\mathrm{MgCl}_{2} \cdot 6 \mathrm{H}_{2} \mathrm{O}$ was adjusted to $25 \mathrm{mg} . \mathrm{L}^{-1}$ ) (Angelidaki et al., 1990), vitamin solution (Touzel and Albagnac, 1983), sodium bicarbonate $\left(400 \mathrm{mg} . \mathrm{L}^{-1}\right)$, LAS $\left(14 \mathrm{mg} . \mathrm{L}^{-1}\right)$, and various co-substrates (methanol, ethanol and yeast extract). The Figure 1 resumes the conditions employed in each stage.

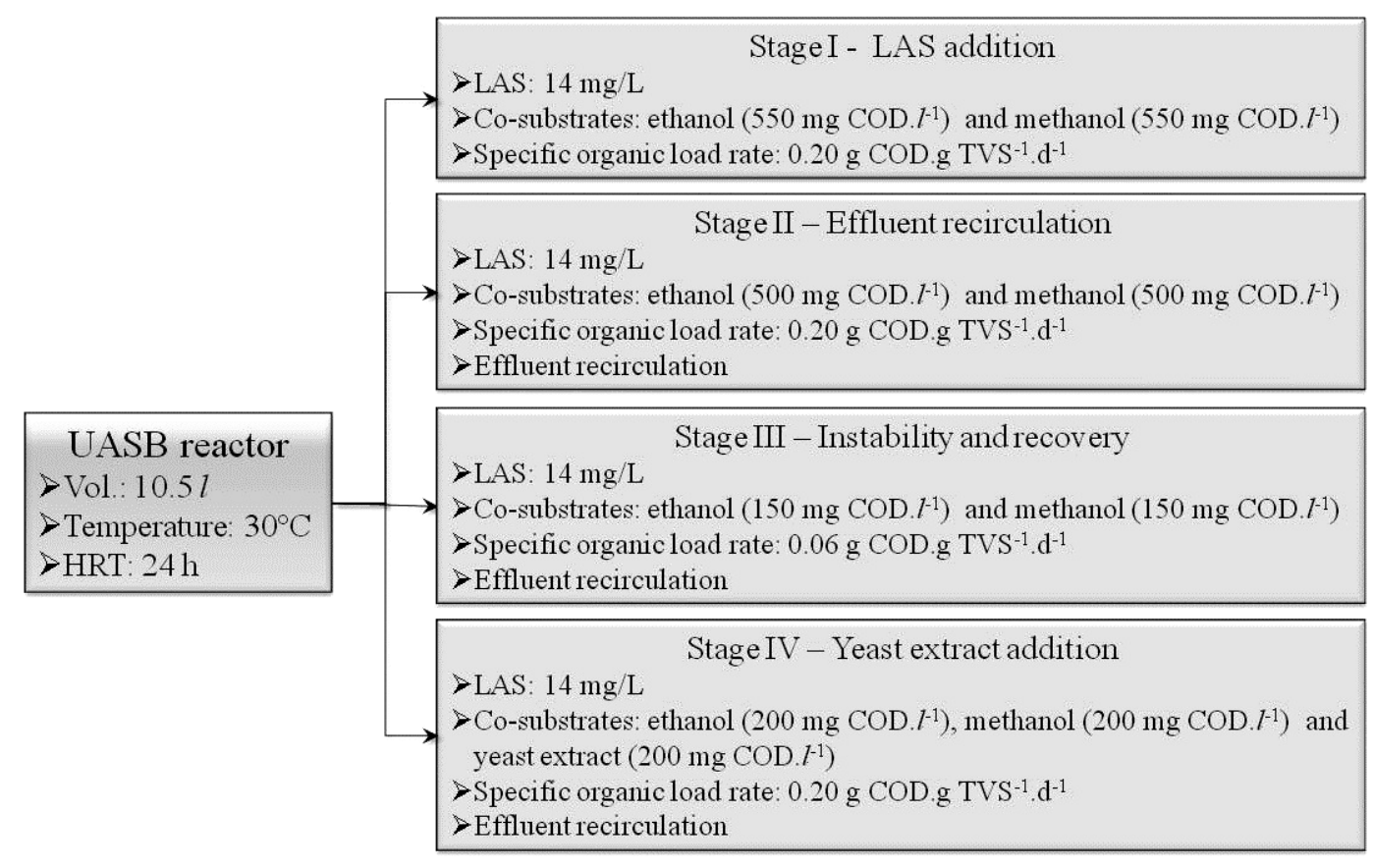

Figure 1: Stages employed in the UASB reactor. 
Prior to LAS addition, the UASB reactor was fed with ethanol as co-substrate for 30 days. In stage I, LAS was added and the co-substrates were ethanol and methanol. Effluent was recirculated in stage II (according to the scheme shown in Figure 2), employing a recirculation flow about five times greater than the influent flow. In stage III, an aeration of the water supply provoked instability in the anaerobic process. This aeration led to decreasing consumption of volatile fatty acids (VFA) since oxygen is lethal to methanogenic archaea. Therefore, to remove excess VFA, the sludge blanket was placed under water, and the reactor medium was drained. Furthermore, the $\mathrm{pH}$ was buffered by adding sodium bicarbonate, and VFA production was controlled by decreasing the co-substrates concentration (specific organic load was $0.06 \mathrm{~g}$ COD.g TVS ${ }^{-1} \cdot \mathrm{d}^{-1}$ while in another stage was $0.2 \mathrm{~g} \mathrm{COD.g} \mathrm{TVS}{ }^{-1} \cdot \mathrm{d}^{-1}$; TVS $=$ total volatile solids; Figure 1). In stage IV, yeast extract was added to compare the removal of LAS fed with complex co-substrate to previous stages with only short-chain alcohols.

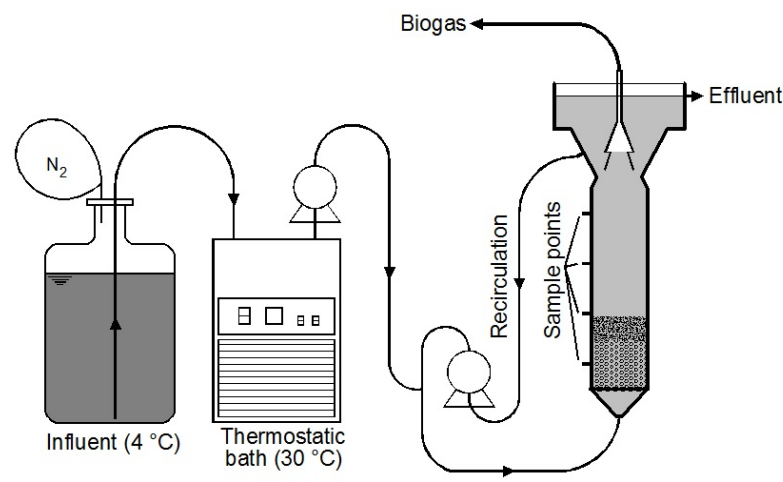

Figure 2: Scheme of the UASB reactor at the stages with effluent recirculation.

\section{Analytical Methods}

The chemical oxygen demand (COD), $\mathrm{pH}$, and solids content were determined according to the Standard Methods of Wastewater Examination (2005), and the alkalinity was quantified by titration (Ripley et al., 1986). The total solids content of the UASB reactor was measured at the end of stages I, III and IV.

VFA were quantified using a Shimadzu GC-2010 gas chromatograph coupled to an HP-Innovax column $(30 \mathrm{~m} \times 0.25 \mathrm{~mm} \times 0.50 \mu \mathrm{m})$ (acetic, butyric, isobutyric, caproic, propionic, valeric and isovaleric) (Moraes et al., 2000).

LAS was determined by high performance liquid chromatography, and a Shimadzu system (LC$10 \mathrm{AD}_{\mathrm{VP}}$ pump, CTO-10A oven and RF-10AXL fluorescence detector) equipped with a reverse-phase C8 column (Supelco) was employed (Duarte et al., 2006). LAS adsorbed on anaerobic sludge was determined according to the protocol described by Duarte et al. (2008).

The granule size was measured at inoculation, the end of adaptation, stages I and IV and the beginning of stage III, according to the protocol described by Alphenaar et al. (1993). Granules from the sludge blanket were transferred to a Petri dish to acquire images. The images were analyzed with Image ProPlus 4.5 software to determine the mean diameter and granule size distribution.

\section{Microbial Community Analysis}

Fluorescence in situ hybridization (FISH) analysis was performed to quantify the microbial composition of Bacteria and Archaea. Samples were collected from the sludge blanket at the end of adaptation, stages I and IV and the beginning of stage III. Oligonucleotide probes ARC915 (Stahl and Amann, 1991), EUB338 (Amann et al., 1990) and NON338 (negative control) (Manz et al., 1992) were used to determine the microbial composition of Bacteria and Archaea. The probes were 5'-end-labeled with rhodamine or CY3, and the fixation and hybridization conditions described by Araújo et al. (2000) were applied. An Olympus BX60 microscope was used to acquire the images, and filter sets for DAPI, rhodamine or CY3 were employed, along with Image ProPlus 4.5 software. To quantify Bacteria and Archaea, Daime 1.3.1 software (Daims et al., 2006) was used to analyze the images.

The most probable number (MPN) technique was performed to estimate the population of total anaerobic bacteria and methanogenic archaea at the end of stage I and IV.

Samples were homogenized with a sterile mortar and pestle. To dilute the samples, phosphate buffer solution $\left(0.8 \mathrm{mM} \mathrm{K} \mathrm{HPO}_{4}, 0.2 \mathrm{mM} \mathrm{K \textrm {K } _ { 2 }} \mathrm{PO}_{4}\right)$ was added under an atmosphere of $\mathrm{N}_{2}(100 \%)$. Samples were diluted from $10^{-1}$ to $10^{-20}$. One milliliter of each sample was transferred in triplicate to flasks under aseptic and sterile conditions. The flasks contained the feed used in each stage. Counting flasks were incubated at $30 \pm 1{ }^{\circ} \mathrm{C}$ for 30 days. The turbidity of the medium was determined to evaluate the presence of total anaerobic bacteria (Vazoller, 1995). Methanogenic archaea was quantified by monitoring methane production (GC) (Vazoller, 1995). Populations were estimated according to the MPN table in Standard Methods of Wastewater Examination (2005). 


\section{RESULTS AND DISCUSSION}

\section{Adsorption Experiment}

The data were fitted to the Freundlich isotherm (Equation (1)):

$$
\mathrm{S}=\mathrm{K}_{\mathrm{f}} \times \mathrm{C}^{1 / \mathrm{n}}
$$

where $\mathrm{S}$ is the adsorbed concentration, $\mathrm{K}_{\mathrm{f}}$ is the adsorption coefficient (L.g TS${ }^{-1}$ ), $\mathrm{C}$ is the equilibrium concentration of LAS (mg. $\left.\mathrm{L}^{-1}\right)$, and $1 / \mathrm{n}$ is a measure of the sorption intensity and describes the degree of curvature of the isotherm.

The results showed that $\mathrm{K}_{\mathrm{f}}=1.03 \pm 0.15$ and $1 / \mathrm{n}=$ $0.88 \pm 0.09\left(\mathrm{R}^{2}=0.9723\right)$ for a mixture of $\mathrm{C}_{10-13}$ homologues (Figure 3 ). These values agreed with the data reported for anaerobic sludge. Mogensen et al. (2003) found that $\mathrm{K}_{\mathrm{f}}=0.796$ and $1 / \mathrm{n}=0.35$ for a $\mathrm{C}_{12}$ LAS. Garcia et al. (2006a) obtained a $\mathrm{K}_{\mathrm{f}}$ of 3.24 and a $1 / \mathrm{n}$ of 0.92 for a LAS mixture containing $\mathrm{C}_{10-14}$ homologues. The observed variation in $\mathrm{K}_{\mathrm{f}}(0.35$ 3.24 ) among studies was attributed to differences in the homologues.

When the value of $1 / \mathrm{n}$ is less than 1 , adsorption becomes more difficult as sorption sites are filled. In contrast, values greater than 1 are indicative of cooperative adsorption. Values of $1 / \mathrm{n}$ close to 1 indicate that the adsorption sites and LAS concentration are independent (Garcia et al., 2002). In the present study, $1 / \mathrm{n}$ was less than 1 , which suggested decreasing adsorption as sorption sites were filled.

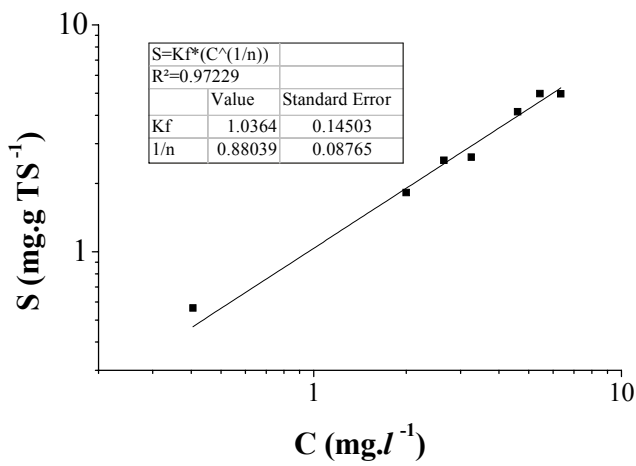

Figure 3: Freundlich isotherm for the adsorption of LAS on inoculum.

\section{UASB Reactor}

The granule size distribution exhibited low variations in the inoculums, adaptation $(30 \mathrm{~d})$ and stages I (140 d), III (77 d) and IV (44 d), for which the mean varied from 2.9 to $3.6 \mathrm{~mm}$ (Figure 4). From stage I to IV, these mean variation decreased to values between 3.2 and $3.6 \mathrm{~mm}$. In stage III, aeration of the water supply provoked a slight decrease in the granule size $(3.2 \pm 0.4 \mathrm{~mm})$, while the addition of yeast extract (stage IV) increased the granule size to $3.6 \pm 0.4 \mathrm{~mm}$. Furthermore, in stage IV, $95 \%$ of the granules possessed a diameter greater than $3 \mathrm{~mm}$.

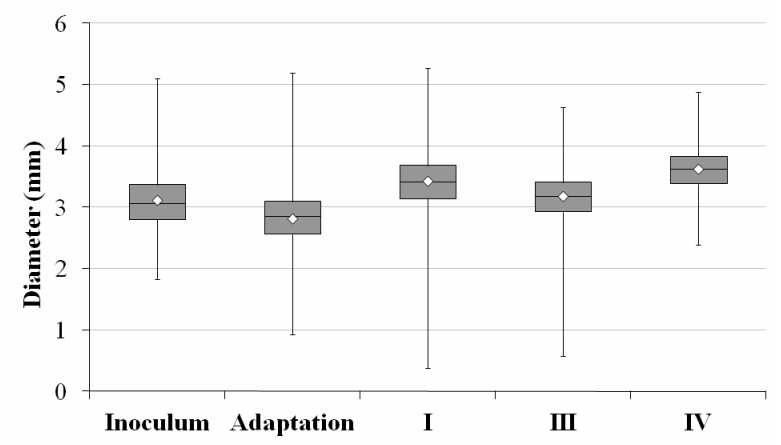

Figure 4: Box plot of the distribution of granule size in the inoculums, adaptation, stage I, III and IV.

The mean COD removal rate was approximately $90 \%$ in all stages, except stage III where the rate decreased to $80 \%$ (Table 1). During stage III, COD removal decreased to $9 \%$ due to aeration of the water supply and, subsequently, the efficiency increased to $80 \%$ after 26 days. In stage IV, the mean COD removal rate increased to $90 \%$.

In all of the stages, the alkalinity and $\mathrm{pH}$ exhibited slight variations. The total alkalinity of the effluent varied from 290 to $360 \mathrm{mg} \mathrm{CaCO}{ }_{3} . \mathrm{L}^{-1}$, and the $\mathrm{pH}$ of the effluent varied from 7.2 to 7.4 (Table 1).

The total suspended solids (TSS) content of the effluent suggested a remarkable loss of solids over time, and values ranged between 30 and $67 \mathrm{mg} . \mathrm{L}^{-1}$. The amount of biomass in the reactor decreased until stage III (from 5.7 to $4.6 \mathrm{~g}$ TS.L ${ }^{-1}$; Table 1). In stage $\mathrm{IV}$, the solids content of the reactor decreased slightly to $4.5 \mathrm{~g}$ TS.L ${ }^{-1}$.

The LAS removal rate was approximately $40 \%$ in stages I and II (Table 1). Due to adsorption of LAS onto biomass, the LAS removal rate was high at the beginning of stage I (between 50 and $90 \%$, Figure 5). In stage I, the LAS content of the effluent increased until the $60^{\text {th }}$ day and stabilized at values around 8$11 \mathrm{mg} . \mathrm{L}^{-1}$ (Figure 5), which indicated decreasing adsorption. When the effluent stabilized (between the $60^{\text {th }}$ day and the end of stage I), the LAS removal rate was $30 \pm 7 \%$. In stage II, the LAS removal rate increased to $41 \%$, due to recirculation of the effluent. Aeration in the water supply decreased LAS removal to $31 \%$ (stage III). Subsequently, the LAS removal rate increased to $50 \%$ in stage IV (addition of yeast extract). 
Table 1: Mean and standard deviation of the parameters analyzed in the UASB reactor.

\begin{tabular}{|c|c|c|c|c|}
\hline Parameter & $\mathbf{I}$ & II & III & IV \\
\hline $\begin{array}{l}\text { Alkalinity }\left(\mathrm{mg} \mathrm{CaCO}_{3} \cdot l^{-1}\right) \\
\text { Effluent } \\
\text { Partial } \\
\text { Total }\end{array}$ & $\begin{array}{l}230 \pm 20 \\
300 \pm 20\end{array}$ & $\begin{array}{l}210 \pm 20 \\
290 \pm 10\end{array}$ & $\begin{array}{l}230 \pm 30 \\
310 \pm 30\end{array}$ & $\begin{array}{l}270 \pm 20 \\
360 \pm 30\end{array}$ \\
\hline \multicolumn{5}{|l|}{ COD } \\
\hline $\begin{array}{l}\left.\text { Influent (mg. } l^{-1}\right) \\
\text { Effluent }\left(\mathrm{mg} . l^{-1}\right) \\
\text { Removal }(\%)\end{array}$ & $\begin{array}{r}1200 \pm 100 \\
130 \pm 60 \\
89 \pm 5 \\
\end{array}$ & $\begin{array}{r}1000 \pm 100 \\
100 \pm 40 \\
89 \pm 3 \\
\end{array}$ & $\begin{array}{r}300 \pm 200 \\
70 \pm 60 \\
80 \pm 20 \\
\end{array}$ & $\begin{array}{r}600 \pm 200 \\
60 \pm 20 \\
90 \pm 2 \\
\end{array}$ \\
\hline \multicolumn{5}{|l|}{ pH } \\
\hline $\begin{array}{l}\text { Influent } \\
\text { Effluent }\end{array}$ & $\begin{array}{l}7.6 \pm 0.1 \\
7.2 \pm 0.1\end{array}$ & $\begin{array}{l}7.5 \pm 0.1 \\
7.2 \pm 0.2\end{array}$ & $\begin{array}{l}7.5 \pm 0.1 \\
7.4 \pm 0.1\end{array}$ & $\begin{array}{l}7.5 \pm 0.1 \\
7.3 \pm 0.1\end{array}$ \\
\hline \multicolumn{5}{|l|}{ LAS } \\
\hline $\begin{array}{l}\text { Influent }\left(\mathrm{mg} \cdot l^{-1}\right) \\
\text { Effluent }\left(\mathrm{mg} \cdot l^{-1}\right) \\
\text { Removal }(\%) \\
\text { Total suspended solids effluent }\left(\mathrm{mg} . l^{-1}\right)\end{array}$ & $\begin{array}{r}14 \pm 1 \\
8 \pm 2 \\
40 \pm 20 \\
44 \pm 8 \\
\end{array}$ & $\begin{array}{r}14 \pm 1 \\
9 \pm 2 \\
41 \pm 9 \\
31 \pm 9 \\
\end{array}$ & $\begin{array}{r}14 \pm 1 \\
10 \pm 2 \\
31 \pm 15 \\
54 \pm 8 \\
\end{array}$ & $\begin{array}{r}14 \pm 1 \\
7 \pm 1 \\
50 \pm 10 \\
67 \pm 9 \\
\end{array}$ \\
\hline \multicolumn{5}{|l|}{ Solids } \\
\hline $\begin{array}{l}\text { Total }\left(\mathrm{g} . l^{-1}\right) \\
\text { Volatile }\left(\mathrm{g} . l^{-1}\right) \\
\text { Fixed }\left(\mathrm{g} . l^{-1}\right) \\
\text { Stage time }(\mathrm{d})\end{array}$ & $\begin{array}{c}5.7 \pm 0.5 \\
4.5 \pm 0.4 \\
1.2 \pm 0.2 \\
140\end{array}$ & $\begin{array}{l}- \\
- \\
- \\
26\end{array}$ & $\begin{array}{c}4.6 \pm 0.5 \\
3.6 \pm 0.4 \\
1.0 \pm 0.3 \\
51\end{array}$ & $\begin{array}{l}4.5 \pm 0.5 \\
3.2 \pm 0.4 \\
1.3 \pm 0.2 \\
\quad 44\end{array}$ \\
\hline
\end{tabular}

LAS removal was associated with the concentration of VFA and instability in the anaerobic process. Between the $80^{\text {th }}$ and $120^{\text {th }}$ days, the LAS removal rate decreased from $56 \%$ to $23 \%$, while the acetic acid content of the effluent ranged from $20-45 \mathrm{mg} \cdot \mathrm{L}^{-1}$. In the beginning of stage III, LAS removal decreased to $20 \%$, and the acetic acid content of the effluent increased to $70 \mathrm{mg} . \mathrm{L}^{-1}$ (Figure 6). In a thermophilic UASB reactor submitted to a temperature reduction from 50 to $32{ }^{\circ} \mathrm{C}\left(30 \mathrm{~h}\right.$, LAS $\left.10 \mathrm{mg} \cdot \mathrm{L}^{-1}\right)$, LAS removal was null, and the VFA content of the effluent was high $\left(300 \mathrm{mg}\right.$ HAc. $\left.\mathrm{L}^{-1}\right)$ (Lobner et al., 2005). The authors (Lobner et al., 2005) reported that LAS removal rates greater than $0.15 \mathrm{mg}$ LAS.g $\mathrm{TS}^{-1} \cdot \mathrm{d}^{-1}$ were obtained at VFA concentrations less than $50 \mathrm{mg} . \mathrm{L}^{-1}$ in the aforementioned reactor.
Namely, inhibition of acetate and propionate degraders has been observed at LAS concentrations of 3-27 mg.L $\mathrm{L}^{-1}$ (Mosche and Meyer, 2002; Garcia et al., 2006b), which increased the VFA content and led to instability in the bacterial consortium. Probably, the instability in the bacterial consortium decreased the LAS removal since the surfactant degradation requires the formation of consortium (Khleifat, 2006; Peressutti et al., 2008). Furthermore, the availability of readily degradable co-substrates, such as VFA, contributed to decreasing the removal of LAS. Sanz et al. (2003) observed a high LAS degradation rate $(85 \%)$ in a UASB reactor after the co-substrates were withdrawn from the medium, while a reactor fed with co-substrates exhibited $64 \%$ efficiency.

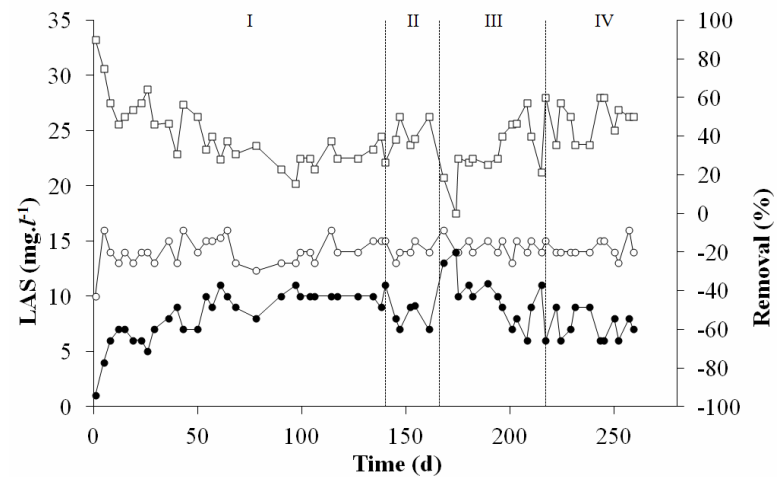

Figure 5: LAS in the influent $(\circ)$, effluent $(\bullet)$ and removal rate $(\square)$.

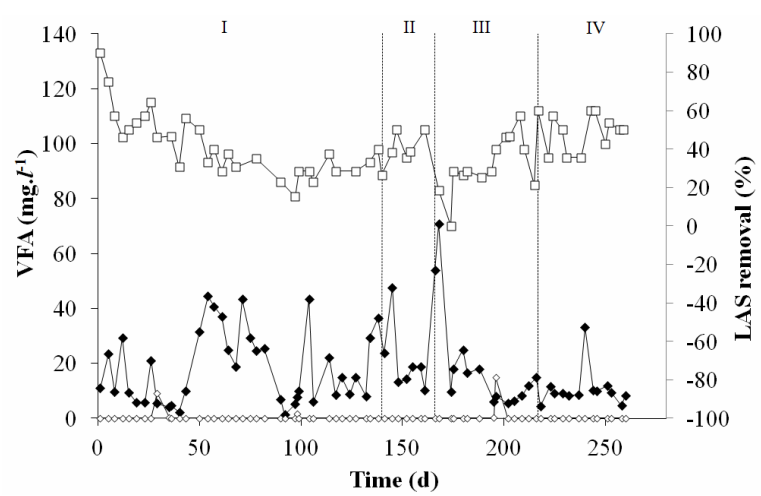

Figure 6: LAS removal ( $\square$ ) and the concentration of acetic $(\diamond)$ and propionic $(\diamond)$ acid. 
According to the mass balance of LAS, the degradation efficiency was equal to $28.5 \%$ (Table 2), which was lower than that (50-85\%) of other UASB reactors under mesophilic conditions $\left(30-37^{\circ} \mathrm{C}\right)(\mathrm{Sanz}$ et al., 2003; Lobner et al., 2005). Namely, the influent concentration used in previous studies was lower than those employed in the present investigation, which decreased the inhibitory potential of LAS (Mosche and Meyer, 2002; Garcia et al., 2006b). Lobner et al. (2005) added $10 \mathrm{mg} \cdot \mathrm{L}^{-1}$ of LAS, and Sanz et al. (2003) added 4-5 mg. $\mathrm{L}^{-1}$. Furthermore, Lobner et al. (2005) used a reactor with an HRT of $48 \mathrm{~h}$, while an HRT of $24 \mathrm{~h}$ was applied in the present study. The high HRT of the aforementioned reactor favored the degradation of recalcitrant substances such as LAS.

Table 2: Mass balance of LAS in the UASB reactor.

\begin{tabular}{|l|r|}
\hline Mass balance (mg) & Final \\
\hline Added & 35,429 \\
Effluent & 23,306 \\
Adsorbed on sludge & 2,016 \\
Degradation & 10,107 \\
(\%) & $28.5 \%$ \\
Time (d) & 261 \\
\hline
\end{tabular}

Using a complex co-substrate (yeast extract), the LAS removal rate was greater $(50 \pm 10 \%)$ than in stages with only short-chain alcohols $(30 \pm 7 \%$ in stabilized stage I and $41 \pm 9 \%$ in stage II). The absence of effluent recirculation in stage I contributed to the greater difference in the LAS removal rate, around $20 \%$, while in stage II this difference was around $10 \%$. Namely, effluent recirculation increases mass transfer, which enhanced LAS removal in an expanded granular sludge bed (EGSB) and fluidized bed reactors (Delforno et al. 2012; Oliveira et al., 2010). Moreover, the rate of biomass loss was $2 \mathrm{mg} \mathrm{TS} . \mathrm{d}^{-1}$ in stage IV (with yeast extract), while this rate was $14 \mathrm{mg} \mathrm{TS} . \mathrm{d}^{-1}$ in stages I and II. The addition of yeast extract provides micronutrients and vitamins that are needed by methanogenic archaea (Boone and Castenholz, 2001); therefore, this addition could have helped to stabilize the bacterial consortium, as seen in previous studies (Abboud et al., 2007; Khleifat, 2006).

\section{Microbial Community Analysis}

According to FISH analysis, the predominant microbial community of the inoculum was methanogenic archaea cells. In the inoculum, probe ARC915 attributed $63 \%$ to Archaea, and probe
EUB338 attributed $37 \%$ to Bacteria. This microbial composition was maintained in adaption and stage I (ARC915 $\approx 64 \%$; EUB338 $\approx 38 \%$ ) until aeration of the water supply (stage III) decreased the amount of archaea cells (48\%) in the microbial composition (Figure 7). After recovery, the microbial composition of archaea cells increased to $60 \%$ in stage IV.

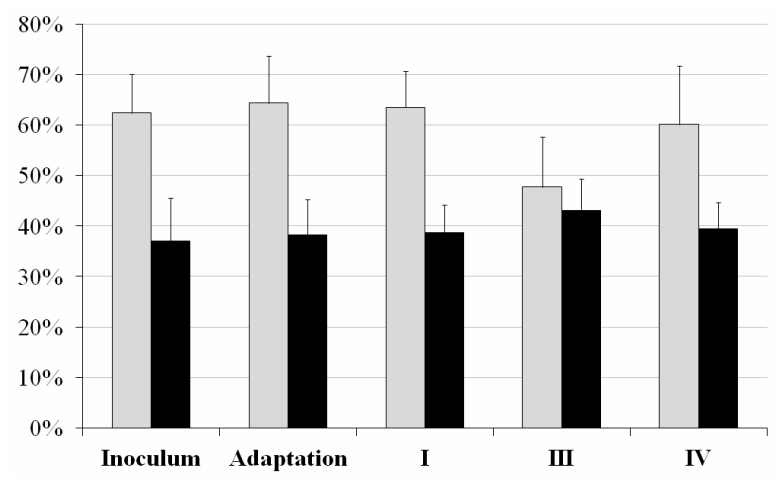

Figure 7: Microbial community composition determined by FISH in the inoculum, adaptation, stages I, III and IV, for probes ARC915 (- $)$ and EUB338 ( $\mathbf{(})$. The error bars indicates standard error.

The total anaerobic bacteria and methanogenic archaea content estimated by MPN increased from stage I to IV. The total anaerobic bacteria content increased from $1.9 \times 10^{8}$ (stage II) to $3.8 \times 10^{11}$ MPN.g $\mathrm{TVS}^{-1}$ (stage IV), and the methanogenic archaea content increased from $1.9 \times 10^{3}$ (stage I) to $4.4 \times 10^{7}$ MPN.g TVS ${ }^{-1}$ (stage IV). The primary differences between stages I and IV were the recirculation of effluent, introduction of instability in the anaerobic process, and yeast extract addition. Among these modifications, only effluent recirculation and yeast extract addition could increase the MPN estimates. The observed increase in the granule size in stage IV (95\% of granules with a diameter greater $3 \mathrm{~mm}$, Figure 4) suggested that the increase in the MPN estimate was due to yeast extract addition.

\section{CONCLUSIONS}

Addition of complex co-substrate (yeast extract) increased the LAS removal to $50 \%$ and efficiencies less than $41 \%$ were obtained using only ethanol and methanol as co-substrates (stages I and II). Using only short-chain alcohols (ethanol and methanol) as co-substrates, the rate of biomass loss was greater $\left(14 \mathrm{mg} \mathrm{TS} . \mathrm{d}^{-1}\right)$ than with yeast extract $\left(2 \mathrm{mg} \mathrm{TS} . \mathrm{d}^{-1}\right)$. Furthermore, an increase in the total anaerobic bacteria and methanogenic archaea content (three 
and four log units, respectively) was related to addition of yeast extract. Therefore, the feeding with complex co-substrates (yeast extract) resulted in greater LAS removal and less biomass loss than feeding with short-chain alcohols (ethanol and methanol). Despite the greater LAS removal using a complex co-substrate, the use of short-chain alcohols is feasible considering the difference in LAS removal rate between stages II and IV (around 10\%), which were maintained similar conditions (effluent recirculation).

FISH analysis suggested that changes in the microbial composition after LAS addition (stage I) were negligible, whereas aeration of water supply (stage III) decreased the amount of methanogenic archaea.

Aerating the water supply increased the acetic acid concentration to $70 \mathrm{mg} . l^{-1}$ and decreased LAS removal to $20 \%$. The observed relationship between the VFA concentration and LAS removal was due to LAS inhibition, which interfered with the bacterial consortium, decreasing LAS removal.

\section{ACKNOWLEDGMENTS}

The authors acknowledge the financial support of Funded by Fundação de Amparo à Pesquisa do Estado de São Paulo (FAPESP), process no. 2009/50427-5.

\section{REFERENCES}

Abboud, M. M., Khleifat, K. M., Batarseh, M., Tarawneh, K. A., Al-Mustafa, A. and Al-Madadhah, M., Different optimization conditions required for enhancing the biodegradation of linear alkylbenzosulfonate and sodium dodecyl sulfate surfactants by novel consortium of Acinetobacter calcoaceticus and Pantoea agglomerans. Enzyme and Microbial Technology, 41, No. 4, p. 432-439 (2007).

Almendariz, F. J., Meraz, M., Soberon, G. and Monroy, O., Degradation of linear alkylbenzene sulphonate (LAS) in an acidogenic reactor bioaugmented with a Pseudomonas aeruginosa (M113) strain. Water Science and Technology, 44, No. 4, p. 183188 (2001).

Alphenaar, P. A., Visser, A. and Lettinga, G., The effect of liquid upward velocity and hydraulic retention time on granulation in UASB reactors treating waste-water with a high sulfate content. Bioresource Technology, 43, No. 3, p. 249-258 (1993).
Amann, R. I., Binder, B. J., Olson, R. J., Chisholm, S. W., Devereux, R. and Stahl, D. A., Combination of 16s ribosomal-RNA-targeted oligonucleotide probes with flow-cytometry for analyzing mixed microbial-populations. Applied and Environmental Microbiology, 56, No. 6, p. 1919-1925 (1990).

Angelidaki, I., Petersen, S. P. and Ahring, B. K., Effects of lipids on thermophilic anaerobicdigestion and reduction of lipid inhibition upon addition of bentonite. Applied Microbiology and Biotechnology, 33, No. 4, p. 469-472 (1990).

Angelidaki, I., Torang, L., Waul, C. M. and Schmidt, J. E., Anaerobic bioprocessing of sewage sludge, focusing on degradation of linear alkylbenzene sulfonates (LAS). Water Science and Technology, 49, No. 10, p. 115-122 (2004).

APHA AWWA and WPCF, Standard Methods for the Examination of Water and Wastewater, 21th Ed., American Public Health Association, Washington, DC (2005)

Araujo, J. C., Brucha, G., Campos, J. R. and Vazoller, R. F., Monitoring the development of anaerobic biofilms using fluorescent in situ hybridization and confocal laser scanning microscopy. Water Science and Technology, 41, No. 12, p. 69-77 (2000).

Boone, D. R. and Castenholz, R. W., Bergey's Manual of Systematic Bacteriology -The Archaea and the Deeply Branching and Phototrophic Bacteria, 2th Ed., Springer, New York, v. 1, (2001).

Daims, H., Lucker, S. and Wagner, M., Daime, a novel image analysis program for microbial ecology and biofilm research. Environmental Microbiology, 8, No. 2, p. 200-213 (2006).

Delforno, T. P., Okada, D. Y., Polizel, J., Sakamoto, I. K. and Varesche, M. B. A., Microbial characterization and removal of anionic surfactant in an expanded granular sludge bed reactor. Bioresource Technology, 107, No. 0, p. 103-109 (2012).

Duarte, I. C. S., Oliveira, L. L., Buzzini, A. P., Adorno, M. A. T. and Varesche, M. B. A., Development of a method by HPLC to determine LAS and its application in anaerobic reactors. Journal of the Brazilian Chemical Society, 17, No. 7, p. 13601367 (2006).

Duarte, I. C. S., Oliveira, L. L., Mayor, M. S., Okada, D. Y. and Varesche, M. B. A., Degradation of detergent (linear alkylbenzene sulfonate) in an anaerobic stirred sequencing-batch reactor containing granular biomass. International Biodeterioration \& Biodegradation, 64, No. 2, p. 129-134 (2010).

Duarte, I. C. S., Oliveira, L. L., Saavedra, N. K. D., Fantinatti-Garboggini, F., Oliveira, V. M. and 
Varesche, M. B. A., Evaluation of the microbial diversity in a horizontal-flow anaerobic immobilized biomass reactor treating linear alkylbenzene sulfonate. Biodegradation, 19, No. 3, p. 375385 (2008).

Garcia, M. T., Campos, E., Dalmau, M., Illan, P. and Sanchez-Leal, J., Inhibition of biogas production by alkyl benzene sulfonates (LAS) in a screening test for anaerobic biodegradability. Biodegradation, 17, No. 1, p. 39-46 (2006a).

Garcia, M. T., Campos, E., Dalmau, M., Ribosa, I. and Sanchez-Leal, J., Structure-activity relationships for association of linear alkylbenzene sulfonates with activated sludge. Chemosphere, 49, No. 3, p. 279-286 (2002).

Garcia, M. T., Campos, E., Sanchez-Leal, J. and Ribosa, I., Effect of linear alkylbenzene sulphonates (LAS) on the anaerobic digestion of sewage sludge. Water Research, 40, No. 15, p. 2958-2964 (2006b).

Khleifat, K. M., Biodegradation of linear alkylbenzene sulfonate by a two-member facultative anaerobic bacterial consortium. Enzyme and Microbial Technology, 39, No. 5, p. 1030-1035 (2006).

Lobner, T., Torang, L., Batstone, D. J., Schmidt, J. E. and Angelidaki, I., Effects of process stability on anaerobic biodegradation of LAS in UASB reactors. Biotechnology and Bioengineering, 89, No. 7, p. 759-765 (2005).

Manz, W., Amann, R., Ludwig, W., Wagner, M. and Schleifer, K. H., Phylogenetic oligodeoxynucleotide probes for the major subclasses of proteobacteria - problems and solutions. Systematic and Applied Microbiology, 15, No. 4, p. 593-600 (1992).

Mogensen, A. S., Haagensen, F. and Ahring, B. K., Anaerobic degradation of linear alkylbenzene sulfonate. Environmental Toxicology and Chemistry, 22, No. 4, p. 706-711 (2003).

Moraes, E. M., Adorno, M. A. T., Zaiat, M. and Foresti, E., Determinação de ácidos voláteis por cromatografia gasosa em efluentes de reatores anaeróbios tratando resíduos líquidos e sólidos. In: VI Oficina e Seminário Latino-Americano de Digestão Anaeróbia, UFPE, Recife, PE (2000). (In Portuguese).

Morita, D. M. and Santana, J. M., Comparação entre o método do azul de metileno e cromatografia líquida de alta pressão (HPLC) para determinação das concentrações de surfactantes aniônicos em esgotos sanitários. In: $23^{\circ}$ Congresso Brasileiro de Engenharia Sanitária e Ambiental. Saneamento Ambiental Brasileiro: Utopia ou Realidade? ABES, Campo Grande (2005). (In Portuguese).
Mosche, M. and Meyer, U., Toxicity of linear alkylbenzene sulfonate in anaerobic digestion: Influence of exposure time. Water Research, 36, No. 13, p. 3253-3260 (2002).

Mungray, A. K. and Kumar, P., Fate of linear alkylbenzene sulfonates in the environment: A review. International Biodeterioration \& Biodegradation, 63, No. 8, p. 981-987 (2009).

Oliveira, L. L., Costa, R. B., Okada, D. Y., Vich, D. V., Duarte, I. C. S., Silva, E. L. and Varesche, M. B. A., Anaerobic degradation of linear alkylbenzene sulfonate (LAS) in fluidized bed reactor by microbial consortia in different support materials. Bioresource Technology, 101, No. 14, p. 51125122 (2010).

Oliveira, L. L., Duarte, I. C. S., Sakamoto, I. K. and Varesche, M. B. A., Influence of support material on the immobilization of biomass for the degradation of linear alkylbenzene sulfonate in anaerobic reactors. Journal of Environmental Management, 90, No. 2, p. 1261-1268 (2009).

Peressutti, S. R., Olivera, N. L., Babay, P. A., Costagliola, M. and Alvarez, H. M., Degradation of linear alkylbenzene sulfonate by a bacterial consortium isolated from the aquatic environment of Argentina. Journal of Applied Microbiology, 105, No. 2, p. 476-484 (2008).

Ripley, L. E., Boyle, W. C. and Converse, L. C., Improved alkalinetric monitoring for anaerobic digestion of high-strength wastes. Journal WPCF, 58, p. 106-111 (1986).

Sanz, J. L., Culubret, E., de Ferrer, J., Moreno, A. and Berna, J. L., Anaerobic biodegradation of linear alkylbenzene sulfonate (LAS) in upflow anaerobic sludge blanket (UASB) reactors. Biodegradation, 14, No. 1, p. 57-64 (2003).

Schörberl, P., Basics principles of LAS biodegradation. Tenside Surfactants Detergents, 26, p. 86-94 (1989).

Stahl, D. A. and Amann, R. I., Development and application of nucleic acid probes, In: Stackebrandt, E., Goodfelow, M., (Ed.), Nucleic Acid Techniques in Bacterial Systematics. John Wiley \& Sons, Ltd., Chichester, United Kingdom, v. 8, p. 207-248 (1991).

Touzel, J. P. and Albagnac, G., Isolation and characterization of Methanococcus-mazei strain MC3. FEMS Microbiology Letters, 16, No. 2-3, p. 241-245 (1983).

Vazoller, R. F., Avaliação do ecossistema microbiano de um biodigestor anaeróbio de fluxo ascendente e manta de lodo, operado com vinhaça sob condições termofílicas. Ph.D. Thesis, Escola de Engenharia de São Carlos, Universidade de São Paulo (1995). (In Portuguese). 